\title{
Pseudotumoral Presentation of Cerebral Amyloid-Beta Angiopathy: Case Report and Review of Literature
}

\author{
Claudia Uribe Roca ${ }^{1}$, Fabio Maximiliano Gonzalez ${ }^{1} \bowtie$, Marta Ines Bala ${ }^{1}$, Miguel Saucedoㄹ, \\ Lucrecia Bandeo', Luciana Leon Cejas', Sol Pacha1, Pablo Bonardo', Carlos Rugilo², \\ Pablo Dezanzo ${ }^{3}$, Rafael Torino ${ }^{4}$, Gustavo Sevlever ${ }^{5}$, Manuel Fernandez Pardal', and Ricardo Reisin ${ }^{1}$ \\ ${ }^{1}$ Department of Neurology, Buenos Aires British Hospital, Buenos Aires, Argentina \\ ${ }^{2}$ Department of Neuroradiology, Buenos Aires British Hospital, Buenos Aires, Argentina \\ ${ }^{3}$ Department of Pathology, Buenos Aires British Hospital, Buenos Aires, Argentina \\ ${ }^{4}$ Department of Neurosurgery, Buenos Aires British Hospital, Buenos Aires, Argentina \\ ${ }^{5}$ Department of Pathology, FLENI, Buenos Aires, Argentina
}

Objective Cerebral amyloid angiopathy-related inflammation (CAA-RI) is a rare and potentially treatable encephalopathy that usually affects people older than 50 years old and has an acute or subacute clinical presentation characterized by rapidly evolving cognitive decline, focal deficits and seizures. In a small subset of patients the disease can adopt a pseudotumoral form in the neuroimages that represents a very difficult diagnostic challenge.

Methods Here in we report a patient with a tumour-like presentation of histopathologically confirmed CAA-RI.

Results We also conducted a search and reviewed the clinical and radiological features of 41 cases of pseudotumoral CAA-RI previously reported in the literature in order to identify those characteristics that should raise diagnostic suspicions of the disease, there by avoiding unnecessary surgical treatments.

Conclusion The therapy of CAA-RI with steroids is usually effective and clinical and radiological remission can be achieved in the first month in approximately $70 \%$ of cases.

Psychiatry Investig 2021;18(6):479-485

Key Words Cerebral amyloid angiopathy, Pseudotumoral, Tumor-like, Neoplasm.

\section{INTRODUCTION}

Sporadic cerebral amyloid angiopathy (CAA) is characterized by deposition of $\beta$-amyloid in the media and adventitia layers of the small and medium-size cortical and leptmeningeal brain arteries and less frequently in veins and capillaries. ${ }^{1}$ CAA is frequent in the elderly. Population-based studies show that the incidence of CAA increases with age: Masuda et al. ${ }^{2}$ studied 400 autopsy cases from Hisayama, Japan and reported an incidence of CAA of $4 \%$ to $10 \%$ in people $50-59$ years old and that rises to $42 \%$ to $45.8 \%$ in those 90 years or older.

Received: May 29, 2020 Revised: August 3, 2020

Accepted: November 1, 2020

$\triangle$ Correspondence: Fabio Maximiliano Gonzalez, PhD

Department of Neurology, Buenos Aires British Hospital, 74 Perdriel St., C1280AEB CABA, Buenos Aires, Argentina

Tel: +541123158460, E-mail: fabiogonzalezclinicas@yahoo.com

(c) This is an Open Access article distributed under the terms of the Creative Commons Attribution Non-Commercial License (https://creativecommons.org/licenses/bync/4.0) which permits unrestricted non-commercial use, distribution, and reproduction in any medium, provided the original work is properly cited.
A more recent autopsy study ${ }^{3}$ performed in 404 communitydwelling persons of an average age at death of 86.5 years old found CAA was present in almost all cases with dementia (94\%) and in most of those without (77\%), while only $1 / 5$ had moderate to severe disease, which is in accordance with previous reports. ${ }^{4}$ In Alzheimer's disease specifically the prevalence reaches $80-90 \%{ }^{2,5}$ Classic clinical presentation includes brain hemorrhages (lobar intracerebral hematoma, cortical microhemorrhage, focal convexity subarachnoid hemorrhage and cortical superficial siderosis) and ischemic lesions (cortical microinfarctions and white matter ischemic changes) ${ }^{2,6}$ In a subset of patients, usually younger, there is inflammation related to CAA that can encompass a range of involvement from only a perivascular lymphocytic infiltrate to a transmural granulomatous destructive angiitis. ${ }^{1}$ Recent reports label this spectrum of inflammatory changes as cerebral amyloid angiopathy-related inflammation (CAA-RI), ${ }^{7}$ which is the term we choose to employ. Clinical syndrome of CAA-RI manifests as subacute cognitive decline, seizures, focal deficits and head- 
aches. ${ }^{1,7-10}$ These clinical symptoms correlate with asymmetric T2-hyperintense leukoencephalopathy on MRI that is responsive to immunosuppressive treatment. ${ }^{1,7-9}$ In rare instances, CAA-RI presents as an infiltrative mass-like lesion mimicking a tumor. ${ }^{10}$ This variant represents a diagnostic challenge and should be recognized to avoid unnecessary surgical procedures. We report a patient with CAA-RI resembling a brain tumor and review similar cases reported in the literature.

\section{CASE PRESENTATION}

A 54-year-old right-handed man developed acute aphasia and confusion followed by a generalized tonic clonic seizure. His past medical history was remarkable for high blood pressure, smoking, chronic obstructive pulmonar disease, depression and a Bell's palsy three years previous to the event. His daily medication consisted of enalapril and clonazepam. Neurological examination revealed non-fluent aphasia. A brain MRI disclosed a left temporal lesion with hyperintense signal in T2-weighted and FLAIR sequences without contrast en- hancement. Diffusion weighted images of temporal lesions did not show restricted diffusivity. Review of T2* weighted gradient echo sequence (GRE) disclosed a few cortical microhemorrhages inside the temporal lesion (Figure 1A-E). A proton MRI spectroscopy of the left lesion revealed no remarkable data. $\mathrm{A}^{11} \mathrm{C}-\mathrm{PiB}$ PET revealed extensive and bilateral brain cortical deposition of $\beta$-amyloid (Figure 1F). CSF exam was normal and the CSF viral polymerase chain reactions including herpes simplex virus type 1 and 2, varicella-zoster virus and enterovirus were negative. The patient was treated with valproic acid and dexamethasone. Laboratory studies including HIV serology, VDRL, eritrosedimentation rate, collagen disease tests and thyroid and paraneoplastic antibodies were negative. An electroencephalogram showed slow left temporal waves. A stereotaxic biopsy revealed pleomorphic and disposition of abigarrated glial cells suggestive of glioma. Resection of the left temporal lesion identified that cortical and leptomeningeal small and medium-sized arterial walls were thickened by an amorphous eosinophilic PAS positive substance that partially or completely occluded the lumen of the
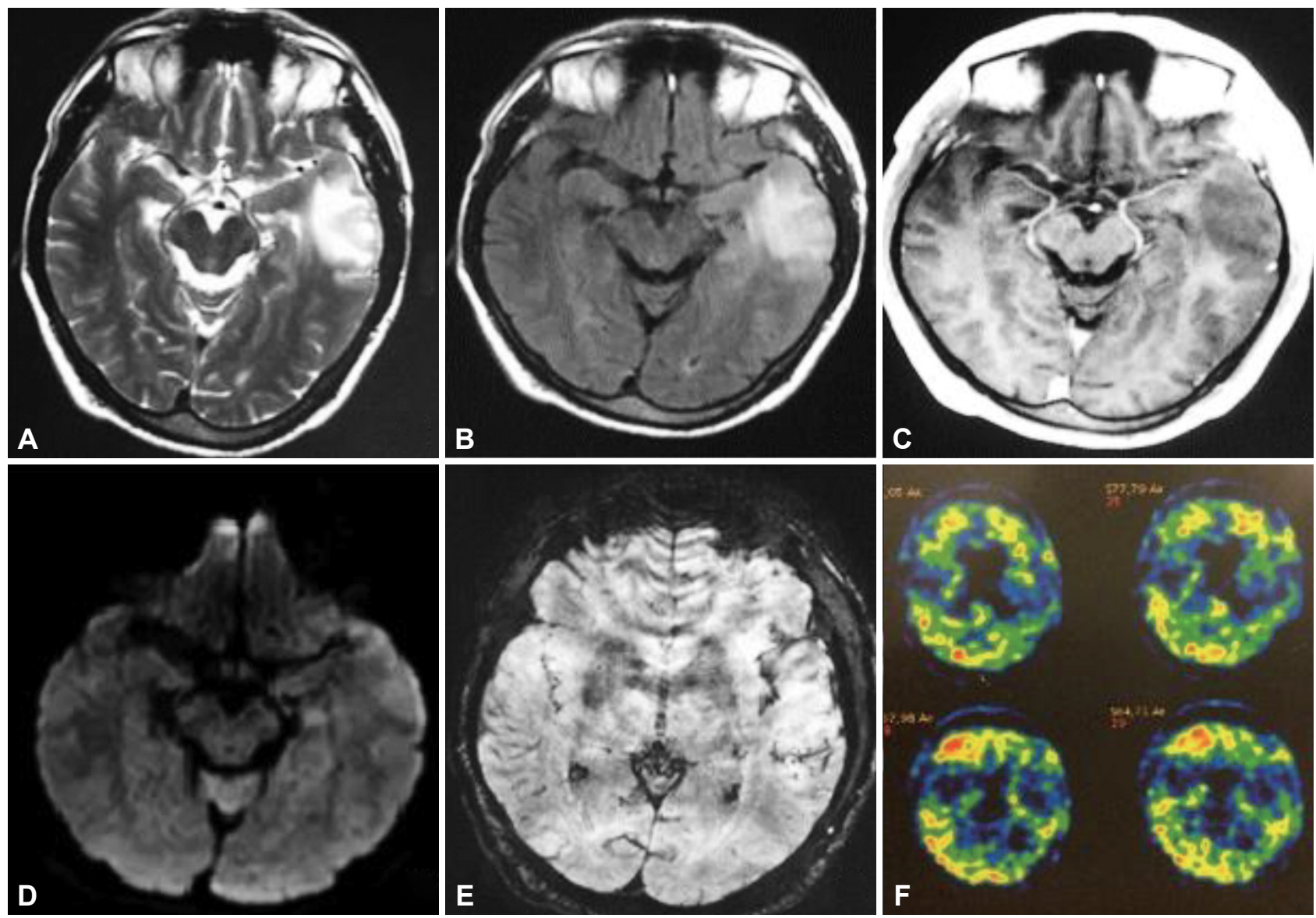

Figure 1. Left anterior temporal lesion with mass effect shows high signal in T2 W (A) and FLAIR (B) and hypointensity in T1W, with lack of contrast enhancement (C). High signal in DWI sequence (D) and ADC map (not shown) is due to vasogenic edema. Scattered intralesional foci of microhemorrhages can be seen in SWI (E). C-PiB PET: Extensive and bilateral cortical deposits of Beta amyloid (F). MRI: magnetic resonance imaging, DWI: diffusion-weighted magnetic resonance imaging, FLAIR: T2-weighted-Fluid-Attenuated Inversion Recovery, ADC map: apparent diffusion coefficient, C-PiB PET: C-Pittsburgh compound B Positron Emission Tomography. 

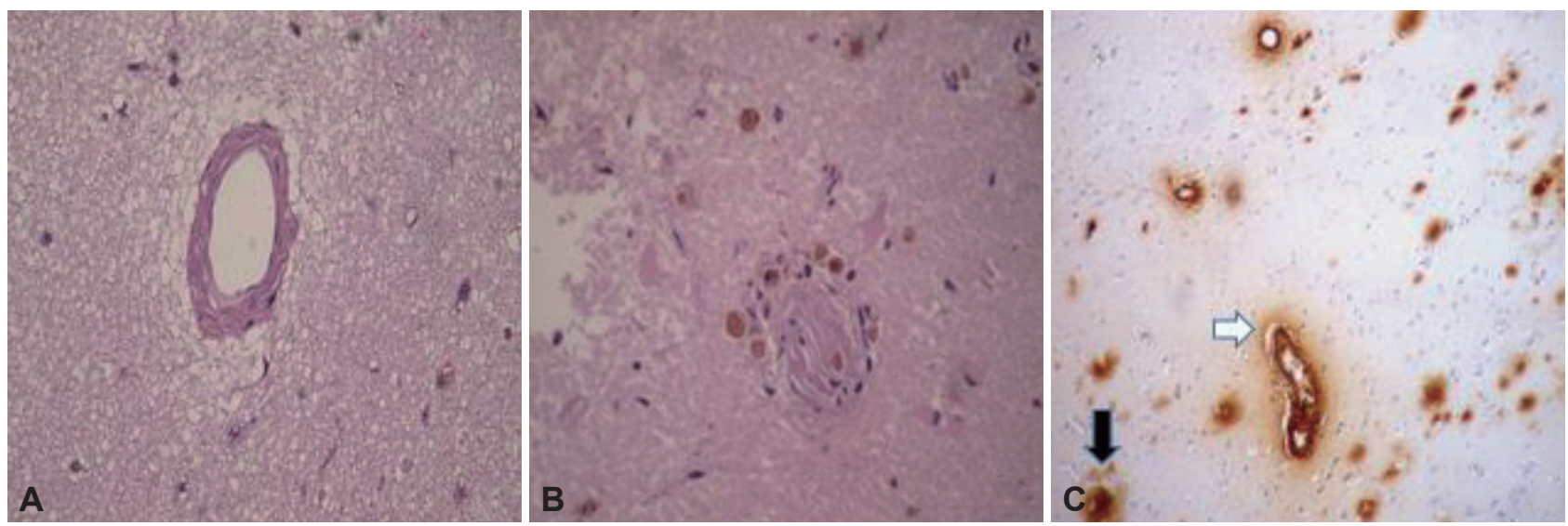

Figure 2. Brain biopsy, hematoxylin-eosin stain where it is observed. A: Homogeneous eosinophilic thickening of the vascular wall. B: Eosinophilic thickening of the parietal wall with peri adventitial hemosiderin deposits (old microhemorrhage). C: Positive immune staining of $\beta$ amyloid in the vascular walls (black arrow) and in plaques within the parenchyma.

vessels. Immunolabeling of arterial wall deposits with $\beta$-amyloid antibodies was strongly positive (Figure 2). Eosinophilic thickening of the parietal wall with peri adventitial hemosiderin deposits (old microhemorrhage) was disclosed. Steroids were gradually tapered. The patient has remained symptom-free after 24 months of follow up and has returned to work.

\section{LITERATURE REVIEW-METHODS}

We searched in Pubmed for relevant articles dating from January 1970 to January 2017 using the following key words: "cerebral amyloid angiopathy" and "pseudotumoral," "tumorlike," "neoplasm," or "mass effect." We decided to include only cases with MRI evaluation and pathologically proven diagnosis of CAA with or without related inflammation, as well as those that met diagnostic criteria proposed by Chung et al. ${ }^{7}$ for probable CAA-RI. All relevant articles were retrieved and checked. We found 27 publications that met inclusion criteria, from which information was extracted for 41 patients. We added our patient, and data was analyzed for age, gender, clinical presentation, brain MRI findings, treatment received and evolution for the 42 cases as a group.

\section{RESULTS}

Our patient presented sudden aphasia and seizures secondary to a tumor-like lesion that resembled a low grade glioma but that finally corresponded to pathology-confirmed CAARI. This tumefactive mass-like aspect has been described in the literature in $15 \%$ of CAA-RI and 14\% of CAA without inflammation. ${ }^{1}$ Most of these latter are probably inflammatory forms of CAA, but a patchy distribution of perivascular lymphocytic infiltrates, ${ }^{7}$ or the possible disappearance of inflammatory infiltrates due to onset of steroid treatment before the performance of cerebral biopsy, could lead to misdiagnosis of CAA-RI as without inflammation. ${ }^{11}$ In a more recent review of CAA-RI, Danve et al. ${ }^{9}$ reported that up to $26 \%$ of CAA-RI cases had mass-like lesions that were usually asymmetrical and either non-enhancing or minimally enhancing. The most frequent brain malignancies suspected in cases of pseudotumoral presentation of CAA-RI were low grade gliomas, ${ }^{12-20}$ lymphomas, ${ }^{21,22}$ multifocal glioma, ${ }^{23,24}$ oligodendroglioma, ${ }^{25}$ gliomatosis cerebrii ${ }^{26}$ and metastases. ${ }^{27}$ The pseudotumoral form of CAA-RI can be a challenging diagnosis, as its clinical and radiological presentation is not specific. ${ }^{10}$ The acute onset of focal neurological deficits in a patient older than 50 years can be initially misdiagnosed as an acute stroke, ${ }^{28}$ especially if the patient has vascular risk factors, as had occurred in our case. However, acute clinical presentation is not infrequent in CAARI patients, as it has been described in up to $54 \%$ of them, ${ }^{9}$ including aphasia in $16.7 \%{ }^{8}$ to $26 \%^{7}$ of cases, and seizures in $31 \%{ }^{7}$ to $36 \%{ }^{8}$ These percentages are similar for the pseudotumoral form of the disease according to our review of 42 cases from the literature: aphasia in 10/42 (23.8\%) and seizures in $16 / 42$ (38\%). However, subacute cognitive decline is the most frequent clinical presentation in our series $29 / 42(69 \%)$, as in others. ${ }^{10,19,29-31}$ Therefore, CAA-RI and its pseudotumoral variant should also be taken into account as a differential diagnosis in any case of rapidly evolving dementia. ${ }^{32,33}$ Headache was present in only $9 / 42(21.4 \%)$, and $62 \%$ of patients in our review presented more than one neurological symptom (Table 1).

Pathogenesis of CAA-RI is not clear. CAA-RI appears to be caused by an autoimmune response to $A \beta$ amyloid. The autoimmune mechanism of the disease is supported by the finding of autoantibodies against beta amyloid 1-40 and 1-42 in blood $^{34}$ and CSF $^{35,36}$ of patients with CAA-RI. DiFrancesco et al. ${ }^{36}$ reported higher titers of autoantibodies against $\beta$ - amyloid 1-40 and 1-42 in CSF of a patient with CAA-RI compared 
Table 1. Clinical, imaging and histopathological findings in 42 patients with pseudotumoral presentation of amyloid angiopathy

\begin{tabular}{|c|c|}
\hline & Total (\%) $(\mathrm{N}=42)$ \\
\hline Age (range), years & $64.74(38-82)$ \\
\hline \multicolumn{2}{|l|}{ Clinical presentation } \\
\hline Subacute cognitive decline & $16(38.09)$ \\
\hline Confusion & $13(30.95)$ \\
\hline Headache & $9(21.43)$ \\
\hline Aphasia & $10(23.81)$ \\
\hline Motor deficits & $11(26.19)$ \\
\hline Seizures & $16(38.09)$ \\
\hline $\begin{array}{l}\text { Others (hemineglect, hemianopia, sensitive } \\
\text { deficit, gait disorder, hallucinations) }\end{array}$ & $9(21.43)$ \\
\hline More than one symptom & $26(61.90)$ \\
\hline \multicolumn{2}{|l|}{ Brain MRI } \\
\hline Unilateral lesion & $26(61.90)$ \\
\hline Bilateral lesions & $16(38.09)$ \\
\hline Contrast enhancement: & $19(45.24)$ \\
\hline Parenchymal & $8(19.05)$ \\
\hline Leptomeningeal & $11(26.19)$ \\
\hline Microbleeds* & $16 / 17(94.12)$ \\
\hline Vasogenic edema in $\mathrm{DWI}^{\dagger}$ & 9/9 (100) \\
\hline \multicolumn{2}{|l|}{ Diagnosis } \\
\hline \multicolumn{2}{|l|}{ Histopathological in 38 patients } \\
\hline CAA & $13 / 38(39.21)$ \\
\hline CAA-RI & $25 / 38(65.79)^{\ddagger}$ \\
\hline $\begin{array}{l}\text { Clinical and MRI diagnostic criteria } \\
\text { for probable CAA-RI in } 4 \text { patients }\end{array}$ & 4 \\
\hline \multicolumn{2}{|l|}{ Pharmacological treatment } \\
\hline Steroids & $27 / 42(64.28)$ \\
\hline CP or MTTX adjuvant to steroids & $7 / 42(16.66)$ \\
\hline Surgical treatment (resection of lesion) $)^{\ddagger}$ & $11 / 42(26.19)$ \\
\hline None treatment & $9 / 42(21.43)$ \\
\hline
\end{tabular}

*T2GRE or other susceptibility magnetic sequences were performed/ informed in only 17 patients, ${ }^{\dagger} \mathrm{DWI}$ was performed /informed in only 9 patients, 拝e of the 11 patients that underwent surgical resection of brain lesion also received steroids. MRI: magnetic resonance imaging, DWI: diffusion-weighted magnetic resonance imaging, CAA: cerebral amyloid angiopathy, CAA-RI: cerebral amyloid angiopathy-related inflammation, CP: cyclophosphamide, MTTX: methotrexate

with age-matched controls that, interestingly, decreased in response to steroid treatment. These autoantibodies might serve as a biomarker of the disease and allow improvement in diagnosis and monitorization of therapeutic response. It remains unclear whether inflammation is triggered by $A \beta$ amyloid or its associated components like ApoE. ${ }^{9}$ There seems to be a strong association of CAA-RI with ApoE genotype $\varepsilon 4 / \varepsilon 4$, as approximately $76 \%$ of patients affected by the disease are ho- mozygotic for this genotype, while only $5 \%$ of subjects with pathologically confirmed noninflammatory CAA present it [odds ratio (OR) 61.7, 95\% CI 7.2 to $706, \mathrm{p}<0.0001] . .^{30}$ We could not perform these tests in our patient.

Brain MRI in CAA-RI cases usually shows a distinctive pattern of asymmetric confluent T-2 hyperintense lesions extending through the cortical and subcortical regions with signal suggestive of vasogenic edema and the presence of multiple cortical or subcortical microbleeds in $\mathrm{T} 2{ }^{*} \mathrm{GRE} / \mathrm{SWI}$ with variable and patchy leptomeningeal and/ or parenchymal contrast enhancement. ${ }^{30}$ Although definitive diagnosis of CAA-RI is still histological, Kinnecom et al..$^{30}$ suggested that a diagnosis of probable CAA-RI might be made on the basis of typical clinical and radiological findings without the performance of a brain biopsy. MRI diagnostic criteria for probable CAA-RI was then proposed by Chung et al. ${ }^{7}$ and recently modified and validated by Auriel et al. ${ }^{37}$ (Table 2).

This diagnostic criteria for probable CAA-RI yields a diagnostic sensitivity and specificity of $82 \%$ and $97 \%$, respectively. ${ }^{37}$ MRI in our patient showed an isolated lesion that was atypical because of its pseudotumoral aspect and the scarcity of cortical microhemorrhages. This latter was a confounding factor in our case: despite performing susceptibility-weighted imaging (SWI) sequences, brain MRI disclosed only a few gathering intralesional microhemorrhage foci that gliomas usually present ${ }^{38}$ and not the multiple cortical or subcortical microhemorrhages inside and outside the lesion that are commonly described in cases of CAA-RI. Other authors have also found the absence of this cortical microhemorrhage in $13 \%{ }^{9}$ to $59 \%{ }^{8}$ of cases. This absence therefore does not discard the diagnosis of CAA-RI. However, as microbleeds can be missed if T2* weighted GRE or other SWI are not performed, we do recommend the inclusion of these sequences as part of MRI protocol to evaluate patients with tumor-like lesions. Only 17 of 42 patients in our series had T2*GRE /SWI sequences, and microbleeds were present in 16 (94\%) of them..$^{38}$

\section{DISCUSSION}

Our patient underwent an open brain biopsy immediately previous to the surgical resection of the brain mass. Although cortical and leptomeningeal tissue was obtained, as it is required to achieve histologic confirmation, ${ }^{10}$ brain biopsy was non-diagnostic in our patient probably because adequate techniques to detect $A \beta$ amyloid were not performed due to lack of diagnostic suspicion. After the surgery, immunolabelling of resected tissue vessels with $A \beta$ amyloid antibodies confirmed amyloid angiopathy, and C-PiB PET imaging revealed extensive $A \beta$ amyloidotic cortical deposits in spite of absence of microhemorrhages in those localizations. MR spectroscopy of 
Table 2. Diagnostic Criteria for Probable CAA-R ${ }^{37}$

1. Age $\geq 40$ years.

2. Presence of $\geq 1$ of the following clinical features: headache, decrease in consciousness, behavioral change, focal neurological signs and seizures. The presentation is not directly attributable to an acute intracerebral hemorrhage.

3. MRI shows unifocal or multifocal white matter lesions (corticosubcortical or deep) that are asymmetric and extend to the immediately subcortical white matter; the asymmetry is not due to past ICH.

4. Presence of $\geq 1$ of the following corticosubcortical hemorrhagic lesions: cerebral macrobleed, cerebral microbleed, or cortical superficial siderosis.

5. Absence of neoplasms, infections, or other cause.

the lesion did not reveal any increment of cholina in this case and was unremarkable in the only 7 patients of our series that underwent this technique.

Treatment of CAA-RI with steroids is usually effective, and clinical and radiological remission can be achieved in the first 3 weeks in approximately $70 \%$ of cases. ${ }^{7,9}$ Many patients remain symptom-free after several years of follow up ${ }^{10,13,14,25}$ but relapses can occur in $26 \%$ of cases, ${ }^{9}$ generally after reduction or cessation of immunosuppression ${ }^{20,27,39}$ therefore, clinical surveillance is necessary, and cyclophosphamide or azathioprine can be added in relapsing disease. ${ }^{20,39}$ In the present pseudotumoral CAA-RI series, 27/42 patients received steroids as therapy, and in 15 of these, steroids were the only pharmacological treatment; 7/27 were also treated with cyclophosphamide or methotrexate as adjuvant therapy. While a review of the literature shows that only approximately $5 \%$ of cases of CAA-RI were surgically treated, ${ }^{8}$ in this series of pseudotumoral form cases of CAA-RI 26\% (11/42) of patients underwent surgical resection of the lesion due to suspicion of underlying malignancy. No treatment was delivered to 9/42 patients. The outcome was favorable (a significant or complete resolution of symptoms) in 19/22 patients treated with only pharmacological therapy, in 6/11 patients that underwent a surgical procedure, and in 5/9 patients that did not receive any specific treatment. Therefore, $71.43 \%$ of patients with pseudotumoral form of CAA-RI in this series had a good outcome. A bad outcome (ongoing deterioration or death) was evident in $14.28 \%$ of cases ( $1 / 22$ patients in the steroid group, in $3 / 11$ patients surgically treated, and in 2/9 patients in the non-treated group). Our patient has not required any further treatment after the initial course of two months of steroids, as he has been symptom-free after 24 months of follow up (Suplementary Table 1 in the online-only Data Supplement). ${ }^{40-45}$

\section{CONCLUSION}

CAA-RI can have an acute clinical presentation that mimics stroke and, in neuroimages, can resemble a tumour. ${ }^{31}$ Differential diagnoses must be done with low grade gliomas and CNS lymphoma. Brain MRI T2 GRE/ SWI sequences should be carefully evaluated when searching for the presence of cortical microbleeds, as they suggest CAA-RI as a possible etiology; however, their absence does not rule out inflammatory amyloid angiopathy. Although in a typical clinical and radiological scenario of CAA-RI a therapeutic trial with steroids is recommended by some authors, ${ }^{7,30,37,39}$ the gold standard for the diagnosis of CAA-RI is still brain biopsy. The pathologist should be aware of clinical suspicions of CAA-RI in order to perform the specific techniques to detect $A \beta$ amyloid.

\section{Supplementary Materials}

The online-only Data Supplement is available with this article at https://doi.org/10.30773/pi.2020.0201.

\section{Acknowledgments}

None.

\section{Conflicts of Interest}

The authors have no potential conflicts of interest to disclose.

\section{Author Contributions}

Conceptualization: Gustavo Sevlever. Data curation: Rafael Torino. Formal analysis: Marta Ines Bala. Investigation: Migue Saucedo. Methodology: Lucrecia Bandeo. Project administration: Luciana Leon Cejas. Resources: Sol Pacha. Supervision: Pablo Bonardo. Validation: Pablo Dezanzo. Visualization: Carlos Rugilo. Writing_original draft: Claudia Uribe Roca, Fabio Maximiliano Gonzalez. Writing_review \& editing: Manuel Fernandez Pardal, Ricardo Reisin.

\section{ORCID iDs}

Claudia Uribe Roca
Fabio Maximiliano Gonzalez
Miguel Saucedo
Lucrecia Bandeo
Luciana Leon Cejas
Sol Pacha
Pablo Bonardo
Carlos Rugilo
Gustavo Sevlever
Ricardo Reisin

https://orcid.org/0000-0002-7531-4827 https://orcid.org/0000-0002-6217-3332 https://orcid.org/0000-0003-4496-5990 https://orcid.org/0000-0002-5584-9701 https://orcid.org/0000-0003-4109-3963 https://orcid.org/0000-0002-3076-6168 https://orcid.org/0000-0002-9778-5128 https://orcid.org/0000-0001-9822-7956 https://orcid.org/0000-0002-9567-7553 https://orcid.org/0000-0002-7278-4639

\section{REFERENCES}

1. Salvarani C, Hunder GG, Morris JM, Brown RD, Christianson T, Giannini C. A $\beta$-related angiitis: comparison with CAA without inflammation and primary CNS vasculitis. Neurology 2013;81:1596-1603.

2. Masuda J, Tanaka K, Ueda K, Omae T. Autopsy study of incidence and distribution of cerebral amyloid angiopathy in Hisayama, Japan. Stroke 
1988;19:205-210.

3. Arvanitakis Z, Leurgans SE, Wang Z, Wilson RS, Bennett DA, Schneider JA. Cerebral amyloid angiopathy pathology and cognitive domains in older persons. Ann Neurol 2011;69:320-327.

4. Neuropathology Group. Medical Research Council Cognitive Function and Aging Study. Pathological correlates of late-onset dementia in a multicentre, community-based population in England and Wales. Neuropathology Group of the Medical Research Council Cognitive Function and Ageing Study (MRC CFAS). Lancet 2001;357:169-175.

5. Brenowitz WD, Nelson PT, Besser LM, Heller KB. Cerebral amyloid angiopathy and its co-occurrence with Alzheimer's disease and other cerebrovascular neuropathologic changes. Neurobiol Aging 2015;36: 2702-2708.

6. Yamada M. Cerebral amyloid angiopathy: emerging concepts. J Stroke 2015;17:17-30.

7. Chung KK, Anderson NE, Hutchinson D, Synek B, Barber PA. Cerebral amyloid angiopathy related inflammation: three case reports and a review. J Neurol Neurosurg Psychiatry 2011;82:20-26.

8. Castro Caldas A, Silva C, Alburquerque L, Pimentel J, Silva V, Ferro JM. Cerebral amyloid angiopathy associated with inflammation: report of 3 cases and systematic review. J Stroke Cerebrovasc Dis 2015;24:20392048.

9. Danve A, Grafe M, Deodhar A. Amyloid beta-related angiitis- a case report and comprehensive review of literature of 94 cases. Semin Arthritis Rheum 2014;44:86-92.

10. Ronsin S, Deiana G, Geraldo AF, Durand Dubief F, Thomas-Maissonneuve L, Formaglio M, et al. Pseudotumoral presentation of cerebral amyloid angiopathy-related inflammation. Neurology 2016;86:912-919.

11. Franco-Macias E, Cerdá-Fuertes N, Rivas-Infante E, Roldán-Lora F, Avila-Polo R, Moniche F. Mainly subarachnoid amyloid angiopathy with pseudotumoral course. Clin Neurol Neurosurg 2016;141:89-91.

12. Osumi AK, Tien RD, Felsberg GJ, Rosenbloom M. Cerebral amyloid angiopathy presenting as a brain mass. AJNR Am J Neuroradiol 1995; 16(4 Suppl):911-915.

13. Polivka M, Vallat AV, Woimant F, Lot G, Boukobza M, Guichard JP, et al. Cerebral amyloid angiopathy (CAA) with presentation as a brain inflammatory pseudo-tumour. Clin Exp Pathol 1999;47:303-310.

14. De Broucker T, Henin D, Claquin G, Vidal J, Stroh-Marcy A, Redondo A, et al. [Cerebral amyloid angiopathy presenting as a pseudotumor: 2 cases with spontaneously favorable outcomes]. Rev Neurol (Paris) 2000; 156:859-863.

15. Oide T, Tokuda T, Takei Y, Takahashi H, Ito K, Ikeda S. Serial CT and MRI findings in a patient with isolated angiitis of the central nervous system associated with cerebral amyloid angiopathy. Amyloid 2002;9: 256-262.

16. Safriel Y, Sze G, Westmark K, Baehring J. MR Spectroscopy in the diagnosis of cerebral amyloid angiopathy presenting as a brain tumor. AJNR Am J Neuroradiol 2004;25:1705-1708.

17. Andrade GC, Silveira RL, Pinheiro N, Jr., Rocha EM, Pittella JE. Cerebral amyloid angiopathy presenting as a brain tumor: case report. Arq Neuropsiquiatr 2006;64:153-156.

18. Karbowniczek A, Wierzba-Bobrowicz T, Mendel T, Nauman P. Cerebral amyloid angiopathy manifested as a brain tumour. Clinical and neuropathological characteristics of two cases. Folia Neuropathol 2012; 50:194-200.

19. Kotsenas AL, Morris JM, Wald JT, Parisi JE, Campeau NG. Tumefactive cerebral amyloid angiopathy mimicking CNS neoplasm. AJR Am J Roentgenol 2013;200:50-56.

20. Bekkelund SI, Midtbu CE. Good outcome in a patient treated for cerebral amyloid angiopathy presenting as an expansive process with inflammation and contrast enhancement. AJNR Am J Neuroradiol 2011;32:E75.

21. Mulvey JM, Hunt J, Spittaler P. Cerebral amyloid angiopathy causing non-hemorrhagic mass effect. ANZ J Surg 2005;75:85-91.

22. Morishige M, Abe T, Kamida T, Hikawa T, Fujiki M, Kobayashi H, et al. Cerebral vasculitis associated with amyloid angiopathy. Neurol Med Chir
(Tokyo) 2010;50:336-338.

23. Caulo M, Tampieri D, Brassard R, Guiot MC, Melanson D. Cerebral amyloid angiopathy presenting as nonhemorrhagic diffuse encephalopathy: neuropathologic and neuroradiologic manifestations in one case. AJNR Am J Neuroradiol 2001;22:1072-1076.

24. Tolchin B, Fantaneanu T, Miller M, Helgager J, Lee JW. Status epilepticus caused by cerebral amyloid angiopathy-related inflammation. Epilepsy Behav Case Rep 2016;6:19-22.

25. Mikolaenko I, Mikolaenko I, Conner MG, Jinnah HA. A 50-year-old man with acute onset generalized seizure. Arch Pathol Lab Med 2006;130:e5-e7.

26. Vandermissen B, Salmon I, Hildebrand J. Recurrent nonhemorrhagic mass lesion due to cerebral amyloid angiopathy. J Neurol 2003;250:239240.

27. McHugh JC, Ryan AM, Lynch T, Dempsey E, Stack J, Farrell MA, et al. Steroid-responsive recurrent encephalopathy in a patient with cerebral amyloid angiopathy. Cerebrovasc Dis 2007; 23 :66-69.

28. Mendonca MD, Caetano A, Pinto M, Vera Cruz e Silva, Viana-Baptista M. Stroke-like episodes heralding a reversible encephalopathy: Microbleeds as the key to the diagnosis of cerebral amyloid angiopathy- related inflammation- A case report and Literature Review. J Stroke Cerebrovasc Dis 2015;24:e245-e250.

29. Scolding NJ, Joseph F, Kirby PA, Mazanti I, Gray F, Mikol J, et al. A $\beta$ related angiitis: primary angiitis of the central nervous system associated with cerebral amyloid angiopathy. Brain 2005;128:500-515.

30. Kinnecom C, Lev MH, Wendell L, Smith SS, Rosand J, Frosch MP, et al. Course of cerebral amyloid angiopathy-related inflammation. Neurology 2007;68:1411-1416.

31. Eng JA, Frosch M.P, Choi K, Rebeck W, Greenberg S. Clinical manifestations of cerebral amyloid angiopathy-related inflammation. Ann Neurol 2004;55:250-256.

32. Geschwind MD. Rapidly progressive dementia. Continuum (Minneap Minn) 2016;22:510-537.

33. Patterson RW, Takada LT, Geschwind MD. Diagnosis and treatment of rapidly progressive dementias. Neurol Clin Pract 2012;2:187-200.

34. Hermann DM, Keyvani K, Van de Nes J, Weimar C, Wiltfang J, Nitsch $\mathrm{RM}$, et al. Brain-reactive $\beta$-amyloid antibodies in primary CNS angiitis with cerebral amyloid angiopathy. Neurology 2011;77:503-505.

35. Piazza F, Greenberg SM, Savoiardo M, Gardinetti M, Chiapparini L, Raicher I, et al. Anti-amyloid $\beta$ autoantibodies in cerebral amyloid angiopathy-related inflammation: implications for amyloid-modifying therapies. Ann Neurol 2013;73:449-458.

36. DiFrancesco JC, Brioschi M, Brighina L, Ruffmann C, Saracchi E, Costantino $\mathrm{G}$, et al. Anti-A $\beta$ Autoantibodies in the CSF of a patient with CAArelated inflammation: a case report. Neurology 2011;76:842-844.

37. Auriel E, Charidimou A, Gurol E, Ni J, Van Etten ES, Martinez-Ramirez $\mathrm{S}$, et al. Validation of clinicoradiological criteria for the diagnosis of cerebral amyloid angiopathy-related inflammation. JAMA Neurol 2016; 73:197-202.

38. Li C, Ai B, Li Y, Qi H, Wu L. Susceptibility-weighted imaging in grading brain astrocytomas. Eur J Radiol 2010;75:e81-e85.

39. Wong SH, Robbins PD, Knuckey NW, Kermode AG. Ceebral amyloid angiopathy presenting with vasculitic pathology. J Clin Neurosci 2006; 13:291-294.

40. Mandybur TI, Balko G. Cerebral amyloid angiopathy with granulomatous angiitis ameliorated by steroid-cytoxan treatment. Clin Neuropharmacol 1992;15:241-247.

41. Ortiz O, Reed L. Cerebral amyloid angiopathy presenting as a nonhemorrhagic, infiltrating mass. Neuroradiology 1996;38:449-452.

42. Fountain NB, Eberhard DA. Primary angiitis of the central nervous system associated with cerebral amyloid angiopathy: report of two cases and review of the literature. Neurology 1996;46:190-197.

43. Schwab P, Lidov HG, Schwartz RB, Anderson RJ. Cerebral amyloid angiopathy associated with primary angiitis of the central nervous system: report of 2 cases and review of the literature. Arthritis Rheum 2003;49: 421-427. 
44. Tamargo RJ, Connolly ES Jr, McKhann GM, Khandji A, Chang Y, Libien J, et al. Clinicopathological review: primary angiitis of the central nervous system in association with cerebral amyloid angiopathy. Neurosurgery 2003;53:136-143; discussion 143
45. Kloppenborg R, Richard E, Sprengers M, Troost D, Eikelenboom P, Nederkoorn PJ. Steroid responsive encephalopathy in cerebral amyloid angiopathy: a case report and review of evidence for immunosupressive treatment. J Neuroinflam 2010;7:18. 


\begin{tabular}{|c|c|c|c|c|c|c|c|c|c|}
\hline $\begin{array}{l}\text { Publication/ } \\
\text { case number }\end{array}$ & $\begin{array}{l}\text { Age } \\
\text { sex }\end{array}$ & $\begin{array}{c}\text { Clinical } \\
\text { presentation }\end{array}$ & T2/FLAIR & $\mathrm{Tl} \mathrm{Gd}$ & T2 GRE & H-MRS & Histology & $\begin{array}{c}\text { Drugs } \\
\text { treatment }\end{array}$ & $\begin{array}{l}\text { Outcome/ } \\
\text { follow up }\end{array}$ \\
\hline \multicolumn{10}{|l|}{ Mandybur 199240 } \\
\hline 1 & $62 \mathrm{~F}$ & Confusion & Isolated, Infiltrative HI & No CE & & & Biopsy: CAA-RI & Steroids+CP & Favorable \\
\hline \multicolumn{10}{|l|}{ Osumi $1995^{12}$} \\
\hline 2 & $59 \mathrm{~F}$ & Headache, motor deficit & Isolated, Infiltrative $\mathrm{HI}(\mathrm{T})$ & No CE & & & Surgery: CAA & Steroids & Death/5 months \\
\hline \multicolumn{10}{|l|}{ Ortiz 1996"41 } \\
\hline 3 & $64 \mathrm{~F}$ & Confusion, headache & Isolated, Infiltrative HI & No $\mathrm{CE}$ & & & Biopsy: CAA & Steroids & Favorable \\
\hline \multicolumn{10}{|l|}{ Fountain $1996^{42}$} \\
\hline 4 & $66 \mathrm{M}$ & $\begin{array}{l}\text { Confusion, cognitive } \\
\text { decline, aphasia }\end{array}$ & Multiple, Infiltrative $\mathrm{HI}$ & No $\mathrm{CE}$ & & & Biopsy: CAA-RI & Steroids, CP & Stable \\
\hline \multicolumn{10}{|l|}{ Polivka $1999^{13}$} \\
\hline 5 & $60 \mathrm{M}$ & Headache & Isolated, Infiltrative HI & No CE & & & Surgery: CAA-RI & None & Favorable $/ 5$ years \\
\hline 6 & $74 \mathrm{~F}$ & Sensori-motor deficit & Isolated, Infiltrative $\mathrm{HI}$ & $\mathrm{CE}$ & & & Surgery: CAA-RI & None & $\mathrm{NI}$ \\
\hline \multicolumn{10}{|l|}{ De Broucker 2000 $0^{14}$} \\
\hline 7 & $64 \mathrm{~F}$ & Seizures & Isolated, Infiltrative HI & No $\mathrm{CE}$ & & & Biopsy: CAA & None & Favorable $/ 2$ years \\
\hline 8 & $69 \mathrm{~F}$ & Aphasia, motor deficit & Isolated, Infiltrative $\mathrm{HI}$ & LCE & MB & & Biopsy: CAA & None & Favorable/1 year \\
\hline \multicolumn{10}{|l|}{ Caulo $2001^{23}$} \\
\hline 9 & $41 \mathrm{M}$ & Headache, seizure & Bilateral infiltrative HI (FTPO) & No $\mathrm{CE}$ & & & Biopsy: CAA & None & $\mathrm{NI} / 1$ year \\
\hline \multicolumn{10}{|l|}{ Oide $2002^{15}$} \\
\hline 10 & $69 \mathrm{M}$ & Cognitive decline, seizure & Multiple, extensive HI & No & & & Biopsy: CAA-RI & None & Ongoing deterioration \\
\hline \multicolumn{10}{|l|}{ Schwab $2003^{43}$} \\
\hline 11 & $74 \mathrm{M}$ & Cognitive decline, seizure & Infiltrative $\mathrm{HI}$ & LCE & & & Biopsy: CAA-RI & Steroids & Favorable/1 year \\
\hline 12 & $70 \mathrm{~F}$ & Seizure & Infiltrative HI & LCE & & & Biopsy: CAA-RI & Steroids $+\mathrm{CP}$ & Favorable/1 year \\
\hline Tamargo $2003^{34}$ & & & & & & & & & \\
\hline 13 & $80 \mathrm{~F}$ & $\begin{array}{l}\text { Confusion, aphasia, } \\
\text { hemineglect }\end{array}$ & Multiple, Infiltrative $\mathrm{HI}$ & Mild CE & & $\mathrm{N}$ & Biopsy: CAA-RI & Steroids & Favorable/1 year \\
\hline Vandermissen $2003^{2}$ & & & & & & & & & \\
\hline 14 & $46 \mathrm{M}$ & Cognitive decline & Isolated, Infiltrative HI & No $\mathrm{CE}$ & & & Biopsy: CAA & None & Stable/11 years \\
\hline Safriel $2004^{16}$ & & & & & & & & & \\
\hline 15 & $49 \mathrm{M}$ & Seizure & Isolated, Infiltrative $\mathrm{HI}(\mathrm{TO})$ & No CE & & $\mathrm{N}$ & Surgery: CAA-RI & Steroids & Favorable/9 months \\
\hline 16 & $71 \mathrm{~F}$ & Cognitive deterioration & Isolated, Infiltrative $\mathrm{HI}(\mathrm{PO})$ & No $\mathrm{CE}$ & & $\mathrm{N}$ & Biopsy: CAA-RI & None & $\begin{array}{l}\text { Ongoing deterioration/ } \\
11 \text { years }\end{array}$ \\
\hline Mulvey $2005^{21}$ & & & & & & & & & \\
\hline 17 & $53 \mathrm{M}$ & $\begin{array}{l}\text { Hemiparesis } \\
\text { Headaches } \\
\text { Seizure }\end{array}$ & Bilateral extensive HI (FTPO) & No $\mathrm{CE}$ & & & Surgery: CAA & Steroids & $\mathrm{NI}$ \\
\hline Scolding $2005^{29}$ & & Seizure & & & & & & & \\
\hline 18 & $70 \mathrm{~F}$ & $\begin{array}{l}\text { Confusion, hallucinations, } \\
\text { reduced conscious level }\end{array}$ & $\begin{array}{l}\text { Temporal lobe swelling Multifocal } \\
\text { WM lesions in occipital lobe }\end{array}$ & $\mathrm{CE}$ & & & Biopsy: CAA-RI & Steroids+CP & Favorable \\
\hline 19 & $72 \mathrm{M}$ & $\begin{array}{l}\text { Hemiparesis } \\
\text { Confusion } \\
\text { Dysphasia } \\
\text { Dyspraxia }\end{array}$ & $\begin{array}{l}\text { Isolated FP diffuse WM HI with mass } \\
\text { effect }\end{array}$ & No $C E$ & & & Surgery: CAA-RI & Steroids & Death \\
\hline Andrade $2006^{17}$ & & & & & & & & & \\
\hline 20 & $45 \mathrm{M}$ & Seizure & Isolated, Infiltrative HI (F) & No CE & & & Surgery: CAA & None & Favorable/6 months \\
\hline Mikolaenko $2006^{25}$ & & & & & & & & & \\
\hline 21 & $50 \mathrm{M}$ & Seizure & Well-circumscri-bed isolated (F) & Mild CE & & & Surgery: CAA-RI & None & Favorable \\
\hline Wong $2006^{39}$ & & & & & & & & & \\
\hline 22 & $79 \mathrm{~F}$ & $\begin{array}{l}\text { Subtle cognitive } \\
\text { dysfunction }\end{array}$ & Bilateral WM HI (FTP) & Mild CE & - & & Biopsy: CAA-RI & Steroids+MTTX & Favorable (1 recidive) \\
\hline McHugh $2007^{27}$ & & & & & & & & & \\
\hline 23 & $80 \mathrm{~F}$ & $\begin{array}{l}\text { Seizures, aphasia, } \\
\text { hemianopia, hemiparesis }\end{array}$ & Bilateral diffuse HI WM (F) & No CE & MB & & Biopsy: CAA-RI & Steroids & $\begin{array}{l}\text { Favorable (2 recidives)/ } \\
24 \text { months }\end{array}$ \\
\hline Kloppenborg $2010^{45}$ & & & & & & - & & & \\
\hline 24 & $74 \mathrm{M}$ & $\begin{array}{l}\text { Gait disorder, } \\
\text { sleepiness seizure, } \\
\text { confusion }\end{array}$ & Bilateral WM HI (F) & $\begin{array}{l}\text { Mild } \\
\text { CE }\end{array}$ & & & Biopsy: CAA-RI & Steroids & Favorable \\
\hline Morishige $2010^{22}$ & & & & & & & & & \\
\hline 25 & $78 \mathrm{~F}$ & $\begin{array}{l}\text { Aphasia } \\
\text { Cognitive decline }\end{array}$ & Unilateral WM HI ( F) & Mild CE & $-\mathrm{NI}$ & & Biopsy: CAA-RI & Steroids & Favorable/ 24 months \\
\hline Bekkelund $2011^{20}$ & & & & & & & & & \\
\hline 26 & $57 \mathrm{M}$ & Crural monoparesis & $\begin{array}{l}\text { Unilateral hemispheric HI lesion } \\
\text { (FTPO) }\end{array}$ & LCE & MB & & Biopsy: CAA-RI & Steroids $+\mathrm{CP}$ & $\begin{array}{l}\text { Favorable (1 recidive)/ } \\
15 \text { months }\end{array}$ \\
\hline Karbowniczek 2012 & & & & & & & & & \\
\hline 27 & $64 \mathrm{~F}$ & Cognitive decline & Two well-delimited HI & No CE & & & Surgery: CAA & None & Cognitive deterioration \\
\hline 28 & $38 \mathrm{M}$ & $\begin{array}{l}\text { Headache, hemiparesis, } \\
\text { aphasia }\end{array}$ & Well-delimited HI & No CE & & & Surgery: CAA & None & Favorable \\
\hline Kotsenas $2013^{19}$ & & & & & & & & & \\
\hline 29 & $63 \mathrm{~F}$ & $\begin{array}{l}\text { Confusion, cognitive } \\
\text { decline, motor and } \\
\text { visual deficit, seizure }\end{array}$ & Isolated, Infiltrative HI (TPO) & Mild LCE & MB & & $\begin{array}{l}\text { Biopsy: Vascular } \\
\text { inflammation }\end{array}$ & Steroids in 3 patients & Favorable \\
\hline 30 & $62 \mathrm{~F}$ & Sensitive deficit & Isolated, Infiltrative $\mathrm{HI}(\mathrm{P})$ & Avid LCE & MB SS & & Biopsy: CAA & & Favorable \\
\hline 31 & $77 \mathrm{M}$ & $\begin{array}{l}\text { Confusion, cognitive } \\
\text { decline, aphasia }\end{array}$ & Isolated, Infiltrative HI (FP) & No $\mathrm{CE}$ & MBSS & & $\begin{array}{l}\text { Biopsy: Vascular } \\
\text { inflammation }\end{array}$ & None in 2 patients & Favorable \\
\hline 32 & $74 \mathrm{M}$ & $\begin{array}{l}\text { Confusion, cognitive } \\
\text { decline }\end{array}$ & Isolated, Infiltrative $\mathrm{HI}(\mathrm{PO})$ & Mild LCE & MB & & Biopsy: CAA-RI & & Favorable \\
\hline 33 & $71 \mathrm{~F}$ & $\begin{array}{l}\text { Confusion, cognitive } \\
\text { decline, headaches }\end{array}$ & Isolated, Infiltrative HI lesion (TPO) & Avid LCE & MB & & Biopsy: CAA-RI & & Favorable \\
\hline Danve $2014^{9}$ & & & & & & & & & \\
\hline 34 & $63 \mathrm{~F}$ & Seizure & Multiple and bilateral HI lesions (FT) & Mild CE & $\begin{array}{l}\text { MB } \\
\text { within lesion }\end{array}$ & & Biopsy: CAA-RI & $\begin{array}{l}\text { Steroids }+\mathrm{CP} / \\
\text { Micopheno late }\end{array}$ & Favorable/11 months \\
\hline Franco-Macias 2016 & & & & & & & & & \\
\hline 35 & $67 \mathrm{~F}$ & $\begin{array}{l}\text { Aphasia } \\
\text { Hemiparesis } \\
\text { Seizure }\end{array}$ & Unilateral extense HI lesion (FTP) & LCE & $\begin{array}{l}\text { No MB. } \\
\text { SS+Old he } \\
\text { mato ma }\end{array}$ & & Biopsy: CAA-RI & Steroids & $\begin{array}{l}\text { Stable (persistent aphasia, } \\
\text { cognitive decline) }\end{array}$ \\
\hline Ronsin $2016^{10}$ & & & & & & & & & \\
\hline 36 & $70 \mathrm{M}$ & Confusion & $\begin{array}{l}\text { Multiple, bilateral, asymmetric HI ST } \\
\text { WM lesions (FTO) }\end{array}$ & LCE & MB, SS & & Biopsy: CAA & Steroids & Death $(\mathrm{ICH}) / 3$ months \\
\hline 37 & $80 \mathrm{M}$ & Subacute cognitive decline & $\begin{array}{l}\text { Multiple, bilateral, asymmetric HI ST } \\
\text { WM lesions (FTO) }\end{array}$ & No CE & MB, SS & $\mathrm{N}$ & & Steroids & Favorable /12 months \\
\hline 38 & $63 \mathrm{M}$ & $\begin{array}{l}\text { Subacute cognitive decline } \\
\text { and motor deficit }\end{array}$ & $\begin{array}{l}\text { Bilateral, asymmetric HI ST WM } \\
\text { lesions }(\mathrm{PO})\end{array}$ & No CE & MB & $\mathrm{N}$ & - & Steroids & Favorable / 24 months \\
\hline 39 & $82 \mathrm{M}$ & $\begin{array}{l}\text { Subacute cognitive decline } \\
\text { and headache }\end{array}$ & Isolated HI ST WM lesion (PO) & LCE & MB, SS & $\mathrm{N}$ & - & Steroids & Favorable /18 months \\
\hline 40 & $63 \mathrm{M}$ & $\begin{array}{l}\text { Subacute cognitive decline } \\
\text { and headache }\end{array}$ & $\begin{array}{l}\text { Extense confluent bilateral asymmetric } \\
\text { HI ST WM lesions (FPO) }\end{array}$ & No CE & MB, SS & $\mathrm{N}$ & & None & Favorable /12 months \\
\hline Tolchin $2016^{24}$ & & & & & & & & & \\
\hline 41 & $52 \mathrm{M}$ & $\begin{array}{l}\text { Confusion, paranoia. } \\
\text { Non convulsive status } \\
\text { epilepticus }\end{array}$ & $\begin{array}{l}\text { Multiple, bilateral, asymmetric HI ST } \\
\text { WM lesions (FTO) }\end{array}$ & No $\mathrm{CE}$ & MB & & Biopsy: CAA & Steroids & Favorable/UK \\
\hline Our patient & & & & & & & & & \\
\hline 42 & $54 \mathrm{M}$ & Acute aphasia, seizure & Isolated, Infiltrative $\mathrm{HI}(\mathrm{T})$ & No $\mathrm{CE}$ & $\begin{array}{l}\text { MB inside } \\
\text { the lesion }\end{array}$ & $\mathrm{N}$ & Surgery: CAA-RI & Steroids & Favorable/24 months \\
\hline
\end{tabular}

